\title{
Cross-Cultural Consumer Attitudes: A Case Of The Second-Hand Clothing Mar- ket In Armenia
}

\author{
Judy G. Newton, (E-mail: jnewton@aua.am), American University of Armenia \\ Nancy J. Scannell, (E-mail: scannell@uis.edu), University of Illinois at Springfield \\ Rubina Ohanian, (E-mail: rubina@ mindspring.com), American University of Armenia and Accenture
}

\begin{abstract}
Under the auspices of the Center for Business Research and Development (CBRD) at the American University of Armenia, and with contributions from assistants: Lusine Poghosyan; Armen Ginosyan; Christina Dombayan; and David Janibekyan, the authors of this article consider the issue of consumer attitudes in Armenia with respect to second-hand clothing. Results of an informal public poll in Yerevan, the country's capital, and a rendering of an historical perspective on Armenia's economy provide a backdrop for discourse on what appears to be a slight shift of consumer attitude away from a relatively negative bias against the purchase of second-hand clothing when compared to that evidenced broadly in the United States.
\end{abstract}

\section{Introduction}

$\mathcal{G}$ lobalization tends to manifest itself in all spheres of life, including economic, political, social, and cultural. In the case of Armenia, its integration into worldwide markets is inevitable, because of its very small domestic market. On the cultural side, the commencement of Armenia's own satellite TV broadcasting makes use of globalization opportunities in bringing cultures into closer and more frequent contact (Apkarian, 1999, p. 63). Aside from Western movies and fast food, Armenia is beginning to experience a slice of life that is relatively commonplace in the U.S. as well as in many other countries - the market for second-hand clothing.

In the U.S., a simple data base search can uncover studies of the operation of used-clothing shops, pricing, and customer profiles (Akron, 1997; Richards, 1977). However, according to USAID Library sources, there are no documents dealing with the subject of second-hand clothing in Armenia (Beteck, 2001). Inquiries made to other major organizations uncovered no studies or data on said subject as well (Ottenbreit, 2001). From observations within the Armenian capital city of Yerevan, however, it is apparent that the second-hand clothing industry is one that has taken hold over the past five years in the market community.

This paper provides a synopsis of informal interviews with primarily Armenians to glean their perspectives on the purchase of second-hand clothing. The paper begins by relating essentials as to the economic, political and cultural environment of Armenia. It is the shocks within the environment, in particular, that of are interest as they precipitated a new humanitarian crisis in a country still in the midst of recovering from the economic and social fallout of an earthquake in 1988 that resulted in the deaths of over 25,000 people and rendered 500,000 homeless (USAID, March 1999).

\section{Economic Crisis in Armenia}

Before the disintegration of the USSR, Armenia, based upon the 1990 Human Development Index (HDI), was ranked $47^{\text {th }}$ among the most advanced countries. Armenia became one among 15 newly independent

Readers with comments or questions are encouraged to contact the authors via email. 
states/countries (NIS, also called Commonwealth of Independent States, or CIS), which emerged after the implosion of the Soviet Union in December 1991 (ANI-Net, 2001), amidst a frenzy of hopefulness and optimism. Notwithstanding, the realization was strikingly different. A few years after the soviet break-up, Armenia, like many of the NIS, was relegated to the second hundred rank, and, hence, a developing country status (Apkarian, 1999). Many of the former Soviet republics had sunk into chaos and despair. Several of these new nations engaged in military conflicts, fueled by a wave of nationalism, ethnic and religious hatred, and territorial tensions that were deep-rooted and, in some cases, centuries old (Burton, 1992).

In 1992, GDP in Armenia fell to about one-third of its 1989 level, realizing a growth rate of negative 46\% and a GNP per capita of approximately $\$ 780$ USD (Library of Congress, 2001). Unemployment ran high, and about $95 \%$ of the population was estimated to live below the official poverty line (U.S. Department of State, May 2, 1994). The official estimate of the general government deficit had widened from about 1\% of GDP to about 10\% in 1992 (EBRD, April 1993). That same year, Armenia's prices of foodstuffs skyrocketed by 32.5 times on average, the lowest increase being attributed to sugar which registered a mere 13.3 multiple (Grigoryan, 1993). With respect to its potential to U.S. investors, the Geonomics Institute of Middlebury, Vermont, USA, assigned a letter grade of $F$ in its evaluation. Thirteen of the 15 NIS countries received a higher grade (USA Today, 1992).

\section{Political Crises in Armenia}

Secession of the Nogorno-Karabakh, a USSR-declared autonomous republic within the republic of Azerbaijan, from Azerbaijan triggered a war between Armenians of Nogorno-Karabakh and Azerbaijan in the early 1990s. The ongoing conflict over the ethnic Armenian-dominated region exacerbated Armenia's severe economic decline. Armenia had been starved of energy, because its Muslim neighbors, Azerbaijan and Turkey put the squeeze on it during the long-running dispute over ownership of the enclave (Isaryan, 1994). Once Armenia was an electricity exporter, thanks to huge oil imports from the rest of the Soviet Union. Without natural resources of its own, however, Armenia could not even keep traffic lights on (The Economist, June 17, 1995). The only way to get goods into Armenia was via three single-lane, rutted roads and an electrified rail line that went dead several times a day (Winestock, 1995).

Additionally, the mid-1990s were marked by two dozen political assassinations (Shabad, 1995). Armenia, once one of the most important industrial centers of the Soviet Union (Geert, 1993) became characterized as the exSoviet Union's worst economy (Levin, 1993). Thus, while free from Moscow's dictatorship, Armenia was also completely cut off from trade partners, who lay sometimes thousands of miles away through several new countries, each with its own customs and border laws. Ironically, the only part of the Soviet Union to benefit from the situation was Moscow, which witnessed a real seven-year economic boom (Ney, 1997).

\section{Exodus of the Armenian Population}

The Seljuk Turk invasion in the $11^{\text {th }}$ century prompted the first large-scale emigration of Armenians, and today, more Armenians live outside of the country than in it (Armenian Travel, 2001). About 500,000 people (12$13 \%$ of the total country's population) left Armenia since 1993. The most intensive migration was to the central and southern regions of the Russian Federation, as well as to various CIS countries. At least 40,000 people left for the United States and other industrialized countries. An estimated $60 \%$ of the total eight million Armenians lives outside Armenia in 60 countries, with one million residing in each of the countries of the U.S. and Russia. Other significant Armenian communities are found in Georgia, France, Iran, Lebanon, Syria, Argentina, and Canada. (Embassy of the Republic of Armenia, 2001). The United Nations Development Program (UNDP) claims that roughly 700,000 people had emigrated from Armenia during 1991 to 1995. The large proportion of highly educated Armenians among the emigrants resulted in a significant brain drain (UNDP, September 1997). Armenia was said to have lost 18\% of its population between 1988 and 1998 (Global IDP, 2000). Between 1995 and 1997, and coinciding with a positive shift in the economy, the emigration declined and an inverse trend emerged - the return of Armenians to their homeland (Khudaverdyan and Sargsyan, 1999).

In earlier times the government used a proxy to estimate the population size by counting loaves of bread sold. A more standard accounting of the Armenia population is expected to be conducted in late 2001, its first since 
1989. There is hesitation on the Armenian Government's part; a confirmation that the population has dropped translates into reduced international funds which are calculated per capita (Kampfner, 2001). A July 2000 estimate put Armenia's population at 3,344,336 (Central Intelligence Agency, 2000).

\section{Currency Depreciation in Armenia}

With the introduction of the Dram in November 1993 as Armenia's national currency, the initial exchange rate of the Dram against the U.S. Dollar was set at 14 Dram. By the end of March 1994, it had reached 230 Dram and ended the year at 400. In 1995, the official Dram rate remained stable moving within a band of 400-410 per USD. In March 1998 \$1 USD was equal to 502 Dram (Hye Etch, 2001). In 1999 and 2000, the end-of-period rates, respectively, were 524 and 522 Drams per USD (IMF, May 2001). During the period, May through July 2001, the rate fluctuated primarily within a range of between 550 to 557 Dram per USD (CBA, 2001).

\section{Armenia's Economic Reforms}

Since its declaration of independence from the Soviet Union by referendum in September 1991, Armenia has been undertaking radical economic reforms, aggressively moving toward a mostly private economy based on market principles (World Bank Group, 2000). Helped by the 1994 Nagorno-Karabakh cease-fire, the Government of Armenia had been able to carry out wide-ranging economics reforms which paid off in dramatically lower inflation and strong economic growth in 1995 (U.S. Department of State, March 1996). Armenia was an exception in this among NIS countries, explained by the law of small numbers, i.e., the rise was from an extremely low base level to which the Armenia economy had slumped to in prior years (Russica, September 10, 1995). Though it missed its inflation target of $10 \%$ in 1997 by over 7 percentage points, the economy grew by $3.3 \%$ in the same year (Financial Times, 1998). Armenia had proved a model of self-discipline, exercising budget-tightening measures that appealed to the IMF (Economist, November 11, 1995). The 1994 launch of its ambitious IMF-sponsored economic program resulted in positive growth rates in 1995-1998 (ANI-Net, 2001). From the HDI standpoint, Armenia made some progress and advanced to the $87^{\text {th }}$ place for 1997 among 174 countries instead of the 99th place in 1996 (Apkarian, 1999).

\section{Privatization in Armenia}

The government's economic reform program had placed emphasis on liberalization, stabilization, and economic restructuring. Most agricultural land was privatized shortly after independence. Price controls applied to a diminishing number of essential goods and services, and was being phased out as a policy (Ney, 1997). Armenia managed to privatize most small- and medium-sized enterprises (Central Intelligence Agency, 2000). Through June of 1999, approximately 1500 medium and large sized enterprises and 6700 small enterprises were privatized (Seta, 2000). Between 1994 to 1999, 6855 small enterprises were privatized through voucher and cash remittances (Ministry of State Property Management, April 1, 2001).

\section{Humanitarian Intervention to Armenia}

Between 1989 and 1995, Armenians lived in the semi-darkness of the Middle ages, having survived without adequate heat, transportation, or medical care. The earthquake of December 7, 1988, which measured 6.7 on the Richter scale, took the lives of 30,000 people, levelled two cities and 55 villages, and destroyed one-tenth of the country's industry (Vardanian, July/August 1996). This contrasts with a quake of comparable magnitude a year later in San Francisco where fewer than 200 died. The difference is largely explained by the fact that hundreds of millions of dollars had been spent in the planning, design and reinforcement of buildings to withstand an earthquake, whereas in Armenia construction costs had been kept to a minimum (McLoughlin, 1990).

The U.S. recognized the independence of Armenia on December 25, 1991, and opened an embassy in the capital, Yereven, in February 1992 (US Department of State, May 2, 1994). Under Operation Provide Hope launched in February 1992, n response to Armenian President Ter-Petrossian's December 8, 1992, declaration of National Emergency, the U.S. delivered food worth about \$3.8 million USD and medicines and medical supplies worth $\$ 6$ million USD to Armenia. The U.S. provided \$12 million USD for earthquake assistance and pledged \$5 
million USD for assistance to Armenian refugees (Adalian, 1994).

Other Humanitarian Aid efforts pumped more than \$400 million USD annually into the economy through in-kind aid, and by Diaspora Armenians sending remittances to families in the republic (Ney, 1997, p.2). Nonetheless, according to the calculations of CIS inter-state statistics committee, the 1999 economy (GDP) of Armenia was operating on the level of the 1970s (Armstat, 2000).

Beginning in 1995, as the humanitarian crises began to lessen and the government of Armenia (GOA) was taking steps toward economic reform, the USAID program gradually began to shift to a more development focus. From 1995 to the present, USAID assistance has increasingly emphasized systemic reform and institution-building as direct humanitarian interventions have gradually declined. This emphasis has assumed a "trickle down" of benefits to the Armenian population, as the laws, regulations, enforcement mechanisms, and institutional structures gradually are intended to improve the climate for economic, political and social development (USAID, March 1999).

\section{Consumer Behavior Models}

Maslow's Hierarchy of Needs model explains why people are driven and motivated by particular needs at particular times, the basic needs - food, shelter and water - being satisfied first (Kotler, 2000). The aforementioned earthquake that devastated Armenia in 1988, relegated its population to the most basic needs level. The quake prompted the first assistance package (\$6 million USD) to the Soviet Union by the United Nations High Commission of Refugees (UNHCR), of which \$4 million USD was earmarked for Armenia (The Economist, Jan 9, 1993). It marked the first occasion since World War II that the Soviet Union accepted disaster assistance provided by the U.S. government (Goldsmith, 1989). The quake also triggered Brittain's biggest initial response to any natural disaster (Randall, 1988), China's first offer of emergency help to the Soviet Union (Donn, 1988), one of the largest disasterrelief operations in the 125-year history of the International Red Cross and Red Crescent Movement (PR Newswire, 1989), and charity concerts across the globe (The Russian Information Agency, 1989).

In 1995 Armenia received \$245.5 million USD in economic aid (About.com, 2001). In more recent years, lobbying groups representing 1 million Armenian Americans have used their wealth, influence and votes to sharply increase U.S. economic assistance to their compatriots overseas. With the help of key members of Congress, they have turned Armenia into one of the largest recipients in recent years of U.S. aid on a per-person basis after Israel. Last year, U.S. aid to Armenia accounted for about $\$ 42$ per person, compared with $\$ 34$ per head for Bosnia, $\$ 3$ for Rwanda, $\$ 1.40$ for Russia and 14 cents for India (Dobbs, 2001).

Notwithstanding the depth and breadth of humanitarian aid to Armenia, only one article was uncovered that explicitly mentions a second-hand clothing shipment to Armenia (Higgins, 1995). Nevertheless, the devastation from the earthquake, in effect, turned the country overnight into a population of charity recipients. Whether this may or may not have an impact on the mindset of Armenians with respect to their way of viewing second-hand clothing, leaning on the 'how' and 'why' of consumer behavior (Mowen and Minor, 1998; Wells and Prensky, 1996), is too great a leap to make.

\section{Armenia and U.S. Comparisons}

Yerevan's second-hand clothing shops sell relatively high-quality garments that originate from Turkey, Syria, China and a few other countries, but are often more expensive even at second-hand prices than new clothing available at local street markets throughout the city. Street markets often stock inventories of lesser quality garments from Chinese and Turkish exporters, but their newness is apparently heavily weighted in the buyer's decision when choosing where to shop. Similar to pricing practices in Yerevan, second-hand clothing stores in the U.S. set prices at a fraction of the original retail value. The discount from new is apparently large enough to outweigh any negative image that used often conjures up (Moffitt, 1983). Indeed, in the U.S. unabashed used-clothing shoppers abound (Thurman, 1996; Cohen, 1994; MacKenzie, 1997).

The picture in Armenia is seemingly different. The results of an earlier survey by the AUA CBRD indi- 
cated that, despite the economic hardships during this period, the negative bias toward used-clothing was strong enough to repel patronage and force second-hand stores - which began to appear around 1993 or 1994 - out of business. Apparently, residents may be reluctant to buy and wear second-hand clothing for fear their neighbors would recognize the conspicuous labels and hence the source of the purchase, and would, accordingly, brand their families as impoverished (Newton, Scannell, and Ohanian, 2001).

In the U.S. the advertising and marketing of second-hand good is relatively sophisticated [(Schiffman and Kanuk (1997); Hoyer and MacInnis (1997); Peter and Olson, (1999)]. At present, advertising, with minor exception, is absent in Armenia's second-hand clothing industry (Newton, Scannell, and Ohanian, 2001).

\section{Public Opinion Poll on Second-Hand Clothing}

Interviews were carried out to elicit feedback from the general public as to their knowledge of and disposition toward used-clothing. The questions were posed loosely in conversational style and in Armenian or English languages, depending on the first-language status of the interviewee. The survey conductor was Armenian who possesses a strong command of the English language. The population sample of 40 was drawn from persons on or in close proximity to the American University of Armenia (AUA), and comprised almost exclusively of Armenians along with one U.S. American, many affiliated with AUA. Findings from the interviews are presented in this paper.

\section{Public Perspective on Second-Hand Clothing in Armenia}

Among the 40 persons polled, 34 or $85 \%$ were women. One of the 40 polled was a U.S. American, the remaining 39 being of Armenian origin. Most were in one way or another affiliated with AUA, and a few were passers-by.

The interviewee was first asked to estimate the number of second-hand clothing shops in Yerevan, and to posit site names if possible. The U.S. American was not aware of any, in concurrence with 7 of the 39 Armenians polled. Of the 32 Armenians who knew of any used-clothing shops, their estimates ranged from 1 to 20, with the highest frequencies of responses - nearly $72 \%$ - falling within the 1-to-4 range. One Armenian male said 20 such shops existed and 4 Armenians each said 10 shops existed in Yerevan. The only sites acknowledged were Grigor Lusavorich and Marshall Baghramyan streets.

The findings are interesting in that Grigor Lusavorich shop is one of the very few that advertises while the Marshall Baghramyan location does not. That both store locations were able to be identified with fairly evenhandedness, despite their respective polar treatment in advertising, might be explained by the fact that polling was conducted on or near Marshall Baghramyan Street, the street on which AUA is situated.

The second question asked whether the interviewee has shopped, does shop or would shop at a second-hand store. Of the 40 polled, 38 or $95 \%$ stated they had never shopped and presently do not shop at second-hand clothing stores because of the very nature that the garments are pre-worn. Eight of the 40 polled, or $20 \%$ said that they would consider shopping at a second-hand clothing store if new-clothing purchases were also an option.

Polled persons responded nearly unanimously - one exception being an Armenian male - in the negative to the question about their propensities to purchase used-clothing for children.

Because of the narrowly defined geographic locale from which the public was sampled, i.e., on or in close proximity to the AUA grounds, the polltaker and some interviewees were likely familiar with each other. It is difficult to state in which directions these conditions biased the respondents' comments.

\section{Consumer Behavior Models}

Numerous influencing factors have been scrutinized in rendering a variety of consumer and communication models, including Philip Kotler's Consumer Behavior Model and Maslow's Theory of Hierarchy [(Hoyer and MacIness (1997); and Kotler (200)]. Explaining consumer behavior involves analyses of cultural (the most heavily 
weighted), social, personal, and psychological factors (Kotler, 2000). Interviews with persons in Armenia indicate that there is an historically strong cultural bias against the purchase of used- clothing. Investigations and research into the Armenian culture by the American University of Armenia's marketing research classes indicate that Armenians are deeply influenced by their heritage, traditions, values, perceptions, friends and preferences of their families.

\section{Post-Purchase Consumer Behavior}

Post-purchase consumer behavior looks at the bases for consumers' decisions once they decide to relinquish a good they had previously purchased. Options include bequeathing, storing, discarding, selling, donating, or renting (Schiffman and Kanuk, 1997). How the consumer makes such a decision, what influences are important, and what is the information acquisition processes that culminates in a subsequent decisive action are studied by Peter and Olson (1999).

In the U.S., post-purchase behavior runs the gamut. For example, the Internal Revenue Service (IRS) allows contributors to deduct the fair market value of clothing donated to charity (Kirwan, 1996; Eichenberger, 1995). Other motives to donate used-clothing are more altruistic: to outfit women on welfare in order to prepare them for job interviews (Alexakis, 1997) or to raise funds for victims of AIDS (Thrift for Aids, 1995).

In strong contrast, and gleaned from numerous conversations with local Armenians, the notion of donating their used-clothing is deemed distasteful at best. This finding coincides with the reality that second-hand shops are primarily stocked with clothing donated from abroad, particularly from Western Europe and the U.S. (Newton, Scannell, and Ohanian, 2001).

Furthermore, in the cases of second-hand clothing shops in the U.S., the market is not only attracting a broader economic echelon of customers, but is a flourishing enterprise for many an entrepreneur (Fox, 1995). Grow Biz International, a Minneapolis-based franchiser, has 814 outlets around the U.S. and is doing brisk business (Hannon, 1995). The net growth of Yerevan's second-hand clothing shops is relatively more modest, and has apparently allowed for an equally modest source of income for Armenian proprietors (Newton, Scannell, and Ohanian, 2001).

The nature and structure of the second-hand clothing stores in Armenia are more standardized than those in the U.S are. In Armenia, differentiation among stores extends for the most part to the occasional sale of non-garment items, e.g., shoes and jewelry, or to a few descriptors in their store monikers (Newton, Scannell and Ohanian, 2001). In the U.S., heterogeneity is more the rule. Some used-clothing shops find it lucrative to specialize in, for example, the vintage look (Center, 1986) or outfits that were cast off by celebrities (Drake, 1994). Nomenclature exercised by U.S. enterprises that trade in used-clothing includes outlets, off-price, discount, consignment, thrift, and sample sales stores (Wilbekin, 1995). And while names of shops in Yerevan are hardly distinguishable, U.S. entrepreneurs exercise a full range of creative business names, such as Second Time Around (Dillingham, 1966) and Value Village (Cohen, 1999).

\section{Future Studies}

Though the second-hand market in Armenia is young, it will be interesting to observe how it may come to compete, if at all, with new-clothing markets, as they sometimes do in the U.S. Also, given the disparity of real incomes between Armenia and the U.S., more information could help identify whether second-hand clothing is considered a normal or inferior good (Parkin, 1990) - in either country. In an age of (sometimes-hyped) conservation, recycling and retailing of used-clothing might be both economically and ecologically beneficial.

\section{References}

1. About.com, Armenia - Country Facts Armenia, sysiwyg://300/http://atheism.about.com, 2001.

2. Adalian, Rouben, Armenia Factbook, Office of Research and Analysis, Armenian Assembly of America, Washington, D.C. and Yerevan, Armenia, 1994, p. 62). 
3. Akron, P.A., Thrift Shops; No End in Sight: Menonite Central Committee, 1997, First-Search.

4. $\quad$ Alexakis, Georgia, Material Issue, U.S. Catholic, Vol. 63, pp. 32-35, December 1997, First-Search.

5. ANI-Net, Armenian National Information Network, excerpts from CIA Word Fact Book, 2001, wwwani.amilink.net/general.htm.

6. Apergis, Nicholis, Black Market Rates and Official Rates in Armenia: Evidence from Causality Tests in Alternative Regimes, Eastern Economic Journal, No. 3, Copyright Eastern Economic Association, Summer 2000, pp. 335-344, First-Search.

7. Apkarian, Gassia, Human Development Report Armenia 1999, Five Years of Human Development in Armenia, United Nations Development Program, 1999, pp. 13-16, 68.

8. Armenian Travel Guide, Armenia Travel Notes, wysiwyg://87/http://www.travelnotes.org/ Europe/Armenia.htm.

9. Armstat, Emigration of the Population and Instability of Jobs Within Employment Area, Statistical Reports, www.armstat.am, 2000.

10. Beteck, Ellis, USAID Library, Development Experience system (DEXS), USAID Development Experience Clearinghouse (DEC), Document Distribution Unit, Arlington, VA, email document, July 12, 2001.

11. Burton, Jonathan, The Great Crack Up, Scholastic Update, Teacher's Edition, Vol. 125, No. 6, Scholastic, Inc., November 20, 1992, First-Search.

12. CBA, Central Bank of Armenia, 2001, www.cba.am.

13. Center for Self-Sufficiency, Thrift Stores and Resale Shops; Suggestive Ideas for Specialized Thrift Shops, Houston, Texas, 1986, p. 13, First-Search.

14. Central Intelligence Agency, CIA- The World Factbook 2000 Armenia, 2000, www.cia.gov/ publications/factbook/geos/am.html

15. Cohen, Rich, Shopping at Sal's, Straight Arrow Publishers, Inc., April 21, 1994, First-Search.

16. Cohen, Shawna, Resale Retail Takes on Mainstream, Marketing Magazine, Vol. 104, No. 28, 1999, p. 4, First-Search.

17. Dobbs, Michael, Foreign Aid Shrinks, but Not for All; With Clout in Congress, Armenia's Share Grows, The Washington Post, January 24, 2001, Section A, p.1, Lexis-Nexis.

18. Donn, Jeff, World Sends Everything From Trained Dogs to Tea for Quake Victims, The Associated Press, International News, December 12, 1988, Lexis-Nexis.

19. Drake, Laurie, Celluloid Couture, Los Angeles Magazine, Vol., 39, No. 2, p. 16, February 1994, FirstSearch.

20. EBRD, Quarterly Economic Review - Armenia, Janet Matthews Information Services, Quest Economics Data Base, April 1993, Lexis-Nexis.

21. Educational Foundation for Nuclear Science, Vol. 50, No. 1, January 1994, First-Search.

22. Eicanberger, Ann, Out With the Old, Washingtonian, Vol. 30, No. 8, pp. 137-139, May 1995, First-Search.

23. Embassy of the Republic of Armenia, Geography / Population, 2001, www.armeniaemb.org.

24. Financial Times London, Hot Water, But Not So Much of It, Financial Times Limited, March 9, 1998, Lexis-Nexis.

25. Fox, Bruce, The New Momentum in Used Merchandise, Chain Store Age, Vol. 71, August 1995, pp. 23-26, First-Search.

26. Geert, Mak, War and Fear Bring Isolation to Armenia, World Press Review, Copyright Stanley Foundation, Vol. 40, No. 10, October 1993, pp. 10-11, First-Search.

27. Global IDP (Internally Displaced Persons) Data Base, Armenia Profile Summary, Global IDP Project of the Norwegian Refugee Council, June 2000, p.1, www.db.idpproject.org/Sites.

28. Goldsmith, Martha, The Armenia Earthquake Elicits Aid from All, Strengthens American-Soviet Ties, The Journal of the American Medical Association, January 20, 1989, Vol. 261, No. 3, p. 341, First-Search.

29. Grigoryan, Victor, Armenia: Wages Lagging Behind Prices, Russica Information Inc., RusData DiaLineBizEkin News, March 12, 1993, Lexis-Nexis.

30. Hannon, Kerry, Think of It as 'Preowned,' U.S. News \& World Report, Vol. 118, June 5, 1995, p. 61-64, First-Search.

31. Hoyer, Wayne D., MacInnis, Deborah, Consumer Behavior, Houghton Mifflin Company, Boston, New York, 1997.

32. Husarska, Anna, Burned-Out, New Republic, Vol. 210, no. 4, January 24, 1994, pp. 11-12, First-Search. 
33. Hye Etch, Currency and Stamps of Armenia; The Currency - Dram, 2001, www.yeetch.narge.com.au/ republic/currency, p.1.

34. Hymen.com, Hymen Travel - Armenia, Hymen Inc., 2000, www.hymen.com/travel/ travelarmeniaquickfacts.htm.

35. IMF, International Monetary Fund, Republic of Armenia: Recent Economic Developments and Selected Issues, IMF Country Report No. 01/78, May 2001.

36. Isaryan, Drastamat, Armenia: Until There are No More Trees, The Bulletin of the Atomic Scientists, 1994.

37. Kampfner, John, Rush to Get Away Before the Lights Go Out, Newspaper Publishing PLC, Independent, 2001, Lexis-Nexis.

38. Khudaverdyan, Knonstantin and Sargsyan, Yeghishe, Armenia, A country and the People, A GuidebookYerevan, Vera Movsessian Publishers, 1999, p. 85.

39. Kirwan, Roberta, Save \$200 or More on Your Clothing Castoffs, Money, Vol. 25, December 1996, p. 27. First-Search.

40. Kotler, Philip, Marketing Management, The Millennium Edition, Prentice Hall International, Inc., 2000.

41. Levin, Steve, Armenia Battles on Two Fronts, The Financial Times Limited, London, April 7, 1993, p. 3, Lexis-Nexis.

42. Library of Congress, Armenia-A Country Study, Country Profile, Economy, 2001, http://lcweb2.loc.gov/frd/cs/amtoc.html.

43. MacKenzie, Robert, WhyThrift Shops Are a Must, New Choices: Living Even Better After 50, Vol. 37 , No. 4, May 1997, First-Search.

44. McLoughlin, Jane, Can You Value Human Life in Money Terms, The Financial Times, London, April 14, 1990, p.1, Lexis-Nexus.

45. Ministry of State Property Management, Data on Privatization Process, April 1, 2001, translated from Armenian to English.

46. Moffitt, Robert, An Economic Model of Welfare Stigma, Institute for Research on Poverty, University of Wisconsin, Madison, 1993, First-Search.

47. Mowen, John. C., Minor Michael, Consumer Behavior, Fifth Edition, Prentice-Hall, Upper Saddle River, New Jersey, 07458, 1998, pp. 252, 253, 578, 579.

48. Newton, Judy; Scannell, Nancy; and Ohanian, Rubina, A Survey of the Second-Hand Clothing Industry in Yerevan, Armenia; Marketing and Economic Aspects, forthcoming, Pakistan Journal of Applied Sciences, Vol. 1, No. 4, 2001.

49. Ney, Richard L., Tour Armenia; A Complete Information and Travel Kit, CD-ROM, Transworld Resources International, Inc, 1997.

50. Ottenbreit, Gerald, Jr., Research Assistant, Armenian Research Center, University of Michigan-Dearborn, Michigan, email document, July 17, 2001.

51. Parkin, Michael, Microeconomics, Addison Wesley Publishers, 1990, p. 73.

52. Peter, J. Paul, Olson, Jerry C., Consumer Behavior and Marketing Strategy, Fifth Edition, Irwin McGrawHill, pp.158-159, 1999, pp. 256-257.

53. PR Newswire, Armenia and the American Red Cross: One Year After, PR Newswire Association, Inc., December 6, 1989, Lexis-Nexis.

54. Randall, Colin, British Aid Floods in for Armenia Victims, The Daily Telegraph, December 10, 1988, p.1, Lexis-Nexis.

55. Richards, Denise, How to Open an Elegant Resale Boutique, Palos Verdes, California, 1977, First-Search.

56. Russica Information Inc., CIS In Figures: Economic Performance In the First Half Of 1995, RusData DiaLine-BizEkon News, September 10, 1995, Lexis-Nexis.

57. Schiffman, Leon and Kanuk, Leslie, Consumer Behavior, Sixth Edition, Prentice-Hall, Upper Saddle River, New Jersey, 07458, 1997, pp. 6-7, 194-195, 258-259, 398-399.

58. Seta, Republic of Armenia: ICT Assessment; 15 July 2000 Version, July 2000.

59. The Economist, An Unusual Armenian Vote-Winner, Vol. 335, No. 7919, June 17, 1995, p. 56, First-Search

60. The Economist, Armenia and Azerbaijan: Still fighting, Vol. 326, No. 7793, January 9, 1993, First-Search.

61. The Russian Information Agency, Charity Concerts for Armenian Quake Victims, ITAR-TASS, March 1, 1989, Lexis-Nexis.

62. Thurman, Judith, Now, Forager, New York Times Magazine, Vol., 10, No. 8, February 25, 1996, 
p. 6, First-Search.

63. UNDP (United Nations Development Program), Development Co-Operation Armenia, September 1997, p. 14.

64. Shabad, Steven, Deadly Politics, World Press Review, Vol. 42, No. 3, March 1995, First-Search.

65. U.S. Department of State, Country Commercial Guides - Armenia, Bureau of Economic and Business Affairs, 1996, pp. 9-13.

66. U.S. Department of State Dispatch, Fact Sheet: Armenia, Vol. 5, May 2, 1994, p.p. 255-7, First-Search.

67. USA Today, Russia Scores High; Armenia, Moldova Flunk, Gannett Company, Inc., Final Edition; August 17, 1992, Lexis-Nexis.

68. USAID, Armenia Strategic Plan FY 1999- FY 2003, March 1999, www.info.usaid.gov/countries/ $\mathrm{am} / \mathrm{strategic.plan/html/str99pub.htm,} \mathrm{pp.} \mathrm{3-4.}$

69. Vardanian, Astghik, Armenia's Choice, The Bulletin of the Atomic Scientists, Vol. 52, July/August 1996, pp. 50-54, First-Search.

70. Wells, William D., Prensky, David, Consumer Behavior, John Wiley \& Sons, Inc., New York, Chichester, Brisbane, Toronto, Singapore, 1996, pp. 208-209, 1996, 312-313, 328-329.

71. Winestock, Geof, After Five Years of Blockade, Armenia Turns the Corner, Journal of Commerce, Inc., August 11, 1995, Front Section, p. 1A, Lexis-Nexis.

72. World Bank Group, Country Brief - Armenia, September 2000, www.worldbank.org.

Notes 